\title{
İskelet metastazlarında minimal invaziv tedaviler
}

\author{
Minimally invasive treatments in skeletal metastases
}

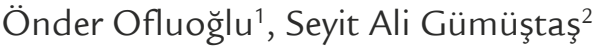 \\ 1Bahçeşehir Üniversitesi Medical Park Göztepe Hastanesi, Ortopedi ve Travmatoloji Anabilim Dalı, İstanbul \\ ${ }^{2}$ Dr. Lütfi Kırdar Kartal Eğitim ve Araştırma Hastanesi, Ortopedi ve Travmatoloji Kliniği, İstanbul
}

\begin{abstract}
Son yıllarda, kanser tedavilerinin gelişimine paralel olarak yaşam süresi uzadıkça, metastatik kemik kanseri ile karşılaşma sıklığımız artmıştır. Kanser tipine bağlı olarak, \%20-85 oranında kemik metastazı görülebilmektedir. İskelet metastazı sonrası prognoz, tümör tipi ve metastazın yaygınlığına bağlı olarak değişir. Ortalama sağkalım bazı tümörlerde aylarla sınırlıkken, yavaş gidişli ve sürekli yeni tedavi seçeneklerinin geliştiği meme, prostat, böbrek ve tiroid karsinomlarında yılları bulabilir. Tümörün tipinden bağımsız olarak, iskelet metastazları, şiddetli ağrı, yürüme güçlüğü ve kırık gelişimine neden olabildiği için, kanserli hastaların yaşam kalitesini ciddi şekilde olumsuz etkileyebilmektedir. İskelet metastazı hastalarının çoğunda, başlangıçta medikal yöntemler (kemoterapi, hormon tedavisi, bisfosfonatlar, denosumab ve analjezikler gibi) ve radyoterapiyle etkili bir ağrı azaltıması sağlanabilir. Ağrılı ekstremite ve omurga metastazlarının palyatif tedavisinde, standart tedavi yöntemleri olan medikal tedavi ve radyoterapinin yetersiz kaldığı ve açık cerrahi girişimleri tolere edemeyecek hastalarda, görüntüleme eșliğinde perkütan termal ablasyon yöntemleri olan radyofrekans ablasyon ve kriyoablasyon etkili ve güvenli yöntemlerdir. Bu endikasyonlara ek olarak, özellikle kemoterapi ve radyoterapi gibi primer tedavilere erken başlanmasının ciddi önem kazandığı olgularda bu yöntemler tercih edilmektedir. Perkütan ablasyon sonrası, trabeküler mikrokırıkların stabilizasyonu ve dayanıklılığının arttırılması için, olguların çoğunda çimento enjeksiyonuna da gerek duyulur.
\end{abstract}

Anahtar sözcükler: kemik çimentosu enjeksiyonu; radyofrekans ablasyon; kriyoablasyon; kemik metastazları
Since the emerging and effective therapies are widely available, and in parallel to this survival of the cancer patients tends to increase, recently the skeletal metastases are more frequently seen. Skeletal metastases are observed in $20-85 \%$ of the patients, depending on cancer type. Prognosis after skeletal metastasis varies depending on tumor type and extent of the metastases. The average survival is limited to months in some cancer types while it may take years in other slowly progressing tumors such as breast, prostate, renal, and thyroid cancers. Regardless of the type of tumor, since skeletal metastases may cause severe pain, or lead to immobilization and pathological fractures, they severely affect the quality of life of cancer patients. In most patients, skeletal metastases are effectively treated by medical methods (chemotherapy, bisphosphonates, hormonal therapies, denosumab, and analgesics) and radiotherapy for palliation of pain. In patients who do not respond these standard palliative therapies, and also cannot tolerate open surgical procedures, minimally invasive thermal ablations, mainly radiofrequency and cryoablation offer alternatives. Moreover, chemotherapy and radiotherapy are preferred especially when it is seriously important to give an early start to primary treatments. In most cases, cement injection may be necessary after percutaneous ablation for trabecular microfractures to regain strength and stabilization.

Key words: bone cement injection; radiofrequency ablation; cryoablation; bone metastasis

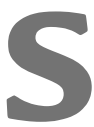
on yıllarda, kanser tedavilerinin gelişimine paralel olarak yaşam süresi uzadıkça, metastatik kemik kanseri ile karşılaşma sıklığımız artmıştır. Kanser tipine bağlı olarak, \%20 -85 oranında kemik metastazı görülebilmektedir. Özellikle meme, prostat ve akciğer kanseri hastalarında, otopsi bulguları hastaların \%85'inde kemik metastazı olduğunu teyit etmektedir. ${ }^{[1]}$ İskelet metastazı sonrası prognoz, tümör tipi ve metastazın yaygınlığına bağlı olarak değişir. Ortalama sağkaIım bazı tümörlerde aylarla sınırlıyken, yavaş gidişli ve sürekli yeni tedavi seçeneklerinin geliştiği meme, prostat, böbrek ve tiroid karsinomlarında yılları bulabilir.

- İletişim adresi: Prof. Dr. Önder Ofluoğlu, Bahçeşehir Üniversitesi Medical Park Göztepe Hastanesi, Ortopedi ve Travmatoloji Anabilim Dalı, İstanbul Tel: 0216 - 4684444 e-posta: oofluoglu@gmail.com

- Gelişstarihi: 26 Ağustos 2019 Kabul tarihi: 31 Ekim 2019 

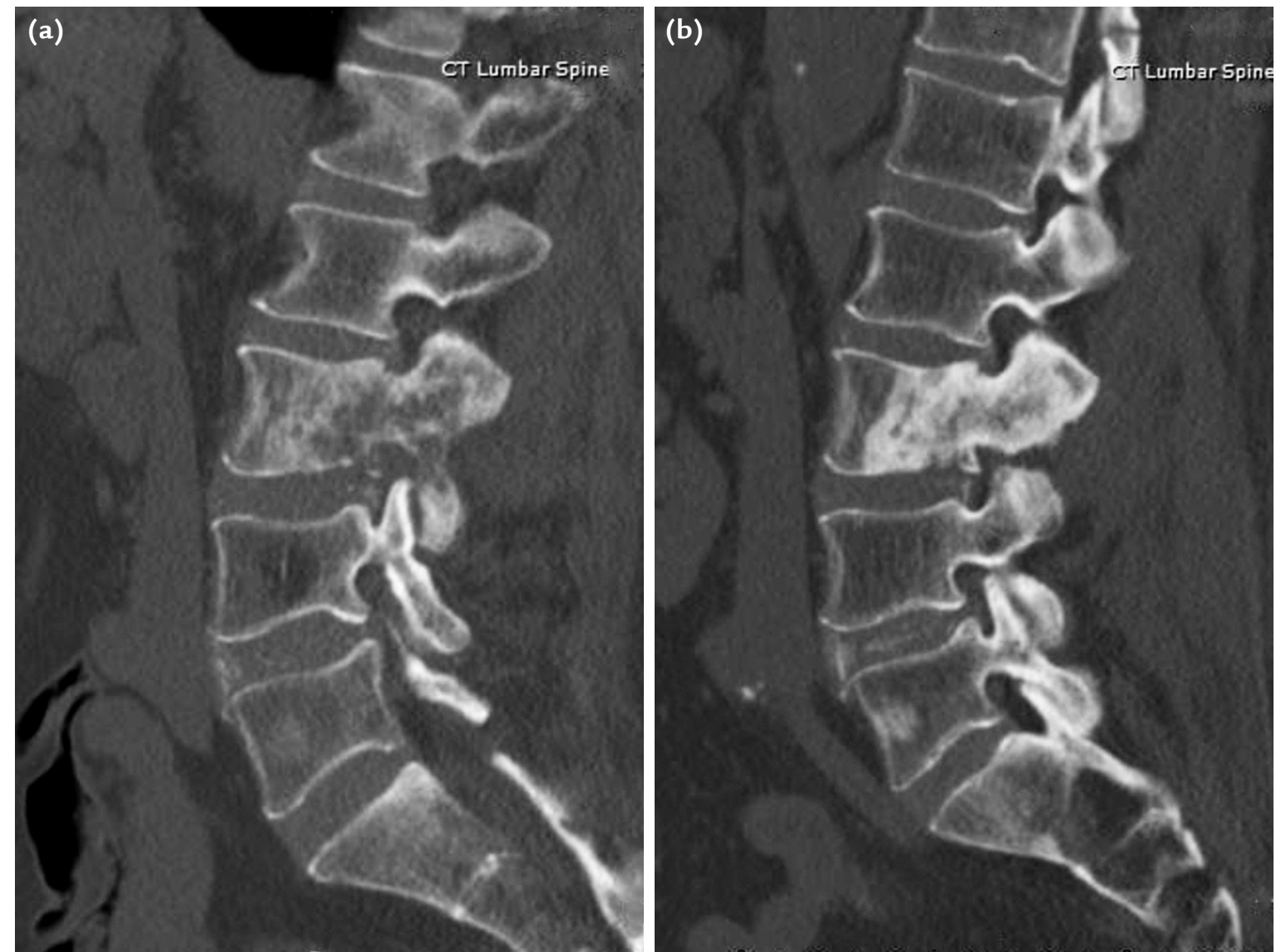

Şekil 1. a, b. Radyoterapi, iskelet metastazlarında birçok olguda ilk seçenektir ve ağrı azalması sağlar. Şekilde, lomber 3. omurgada pediküle ve nöral foramene uzanım gösteren karsinom metastazında radyoterapi sonrası klinik ve radyolojik tam yanıt elde edilmiştir.

Tümörün tipinden bağımsız olarak, iskelet metastazları, şiddetli ağrı, yürüme güçlüğü ve kırık geliş̧imine neden olabildiği için, kanserli hastaların yaşam kalitesini ciddi şekilde olumsuz etkiler. ${ }^{[2,3]}$

İskelet metastazı hastalarının çoğunda, başlangıçta medikal yöntemler (kemoterapi, hormon tedavisi, bisfosfonatlar, denosumab ve analjezikler gibi) ve radyoterapi (RT) ile etkili bir ağrı azaltılması sağlanabilir. Hastaların \%60'ında standart tedavi yöntemleri etkiliyken, yalnızca üçte birinde tam tümör cevabı elde edilebilmektedir (Şekil 1). Dolayısı ile, azımsanmayacak sayıda hastada progresyon görülmekte ve standart tedavi yetersiz kalmaktadır. Özellikle, radyorezistan tümörler (böbrek, kolon, küçük hücreli dışı akciğer kanseri, tiroid, hepatosellüler karsinom, melanom ve sarkom gibi) bu açıdan riskli grubu oluşturur. Ayrıca, RT sonrası ağrının hafifletilmesi ihtiyacı, yaklaşık 2-3 hafta içinde ortaya çıkmaktadır. Cerrahi tedavi, özellikle nörolojik defisiti olan olgularda en-blok vertebra rezeksiyonu sağkalıma katkı sağlayabileceğinden dolayı, nispeten yavaş gidişli karsinomların tekil metastazlarında ve açık cerrahi tedaviyi tolere edebilecek sistemik ve immün durumu iyi hastalarda endikedir. Ancak, metastatik hastaların, kötü genel durumları ve kısa yaşam beklentileri nedeniyle, cerrahi için kötü adaylar oldukları ve bu hastalarda uygulanacak majör cerrahinin yüksek komplikasyon taşıdığı, bunların cerrahi sonrasında uygulanacak kemoterapi (KT) ya da RT'de gecikmeye neden olabileceği dikkate alınmalıdır. ${ }^{[2,4]}$

Bunların dışında kalan, yani standart tedaviye rağmen ağrı azalması yetersiz olan ve açık cerrahiyi tolere edemeyecek hastalarda; minimal invaziv tedaviler, başlıca perkütan vertebroplasti (PVP) ve perkütan kifoplasti (PKP) ve termoablasyon yöntemleri olan radyofrekans ablasyon (RFA) ve kriyoablasyon (KA) birçok hastada alternatif ve etkili tümör ablasyonu, mekanik stabilizasyon ve ağıının azalmasını sağlayabilmektedir. 


\section{KEMIK ÇIMENTOSU (PMMA - polimetil metakrilat) ENJEKSIYONLARI}

\section{Perkütan Vertebroplasti (PVP), Perkütan Kifoplasti (PKP) ve Osteoplasti}

Perkütan segment enjeksiyonunun, ilk kez 1987'de, Galibert ve ark. tarafindan servikal vertebra hemanjiyomunda uygulanmasının ardından, yöntemin ağrı azaltılması ve mekanik stabilizasyon açısından etkinliği ve güvenilirliği görülmüş ve ardından, bu yöntem gerek metastatik gerekse osteoporotik vertebra kırıklarında yaygın kullanılan standart bir yaklaşım olarak uygulanmaya başlanmıştır. ${ }^{[5]}$ Kifoplasti yöntemi ise, balon yardımıyla oluşturulan boşluğa, düşük basınçla ve kontrollü çimento enjeksiyonu sağlayan daha güvenli bir yöntem olarak geliştirilmiştir. Bunların her ikisi de, özellikle beklenen yaşam süresi kısa ve yüksek riskli metastatik omurga hastaları için, palyatif yöntemler olarak açık cerrahiye alternatif teşkil etmektedir. PVP ve PKP, medikal tedavi ya da RT'ye alternatif bir yöntem olmadığı gibi, en blok rezeksiyonun sağkalıma katkıda bulunacağı nispeten yavaş gidişli karsinomların tekil metastazlarında da önerilmez. Kesin kontrendikasyonları arasında; tedavi yapılacak omurga segmentinde enfeksiyon, tedavi edilemeyen koagülopati ve yöntemi uygularken kullanılacak herhangi bir materyale aşikar alerji, sayılabilir. Benzer şekilde, ilerleyici nörolojik defisit, doğal olarak açık dekompresyonla tedavi edilmelidir. Son olarak; omurgada çok sayıda vertebra cismini işgal eden diffüz tutuluma bağlı ağrıda, çimento enjeksiyonlarının yeterli azalma sağlayamayabileceği bilinmelidir.

Göreceli kontrendikasyonlar arasında; aksiyelden ziyade radiküler kökenli ağrı, omurga cisminde ciddi çökme (vertebra yüksekliğinin 2/3'ünden fazla), tümörün posterior duvarı destrükte etmesi ve epidural yayılım, sayılabilir. ${ }^{[6]}$ Ancak bazı yayınlarda, epidural yayılımın olduğu ama nörolojik defisitin olmadığı hastalarda da iyi sonuçlar alınabileceği bildirilmektedir. ${ }^{[7]}$

PVP ve PKP sıklıkla lokal anestezi ve bilinçli sedasyon altında uygulanmaktadır. Birçok olguda yöntem floroskopi altında uygulanabileceği gibi, özellikle pedikülleri destrükte eden tümörlerde ve ileri derecede osteoporotik hastalarda, çalışma kanüllerinin doğru yerleştirilmesi açısından bilgisayarlı tomografi (BT) kullanılması daha güvenli görünmektedir. Yöntem daha çok lomber ve torakal vertebrada uygulanmaktaysa da, uygun servikal omurga lezyonlarında da anterior yaklaşımla PVP yapılabilir. Yine, üst ve orta torakal omurgalarda pedikül boyutunun küçük olması nedeniyle, parapediküler yaklaşım tercih edilmektedir. Ancak bu yöntemin de, transpediküler girişe göre hemotoraks, pnömotoraks ve paravertebral hematom riski taşıdığı göz önünde tutulmalıdır. Omurgada kemik metastazlarının göreceli olarak sık görüldüğü bölgelerden biri olan sakrumda, gerek primer tümoral infiltrasyona bağlı gerekse radyasyon sonrası sakral yetmezlik kırıklarında kemik çimentosu enjeksiyonu, gerektiğinde RFA ile kombine edilerek, oldukça etkili bir ağrı azalması sağlar (Şekil 2). ${ }^{[8]}$

Uygulamanın üni- ya da bi-pediküler girişimle yapılması ve sement enjeksiyonunun miktarı, lezyonun vertebra içindeki yayılımı ve yerleşimine bağlı olarak değişiklik gösterir. Tüm vertebral kavitenin kemik çimentosuyla doldurulması, neoplastik dokunun yayilımına yol açabileceğinden önerilmemektedir. PVP/PKP yöntemlerinin radyosensitif tümörlerde RT, radyorezistan tümörlerde ise RFA ile kombinasyonu, bu komplikasyonun önlenmesi açısından önemlidir.

Gerek geriye dönük gerekse ileriye dönük birçok çalışmada PVP/PKP yöntemlerinin ağrı üzerinde oldukça etkili olduğu gösterilmiştir. Analjezik etkinin başlıca, trabeküler mikrokırıkların stabilizasyonu yanı sıra, çimentonun kimyasal ve termal toksik etkilerinden kaynaklandığı düşünülmektedir. ${ }^{[9-11]}$

Omurganın mekanik stabilitesi ile enjekte edilen çimento miktarı arasında doğrudan bir ilişki olmadığı, bazı olgularda $2 \mathrm{~mL}$ çimento enjeksiyonunun bile yeterli olabileceği bilinmektedir; bununla birlikte torakolomber bölgede ortalama 4-6 mL çimento enjeksiyonu önerilir.

PVP/PKP, osteoporotik hastalardaki uygulamalarla kıyaslandığında, metastatik hastalarda daha yüksek komplikasyon oranlarıla birliktedir. Yüzeyel enfeksiyon, işlem sırasında kot, posterior elemanlar veya pedikülde kırık oluşması ve hematom oluşması, minör komplikasyonlar olarak değerlendirilir.

Çimento kaçağı, her iki yöntemde de önemli bir endişe kaynağıdır. Metastatik olgularda çimento kaçağı, kortikal destrüksiyonun lokalizasyonuna bağ|ı olarak, lateral, anterior veya daha önemlisi posterior epidural bölgede görülebilir (Şekil 3). Birçok olguda çimento kaçaklarının asemptomatik olduğu bilinmektedir. Cotten ve ark., 40 metastatik olguda uyguladıkları PVP'lerin 29'unda, ameliyat sonrası BT'de kaçak görüldüğünü bildirmişlerdir. Bu seride çimento kaçakları, sırası ile paravertebral, spinal kanal, nöral foramen, komşu disk ve lomber venöz pleksusa olmuştur. Bu yüksek orana rağmen yazarlar, yalnızca iki olguda dekompresyon gerektiğini belirtmektedirler. ${ }^{[12]}$

Ağrı azaltılması ve mekanik stabilizasyon üzerinde her iki yöntem de etkili görünmektedir. Bae ve ark., 342 hastayı içeren çalışmalarında, PVP ve PKP uygulamalarının sonuçlarını geriye dönük olarak değerlendirmişler ve iki yöntem arasında uygulanabilen sement miktarı, ağrının azalması ve fonksiyonel sonuçlar açısından bariz bir fark olmadığını belirtmişlerdir. ${ }^{[13]}$ 


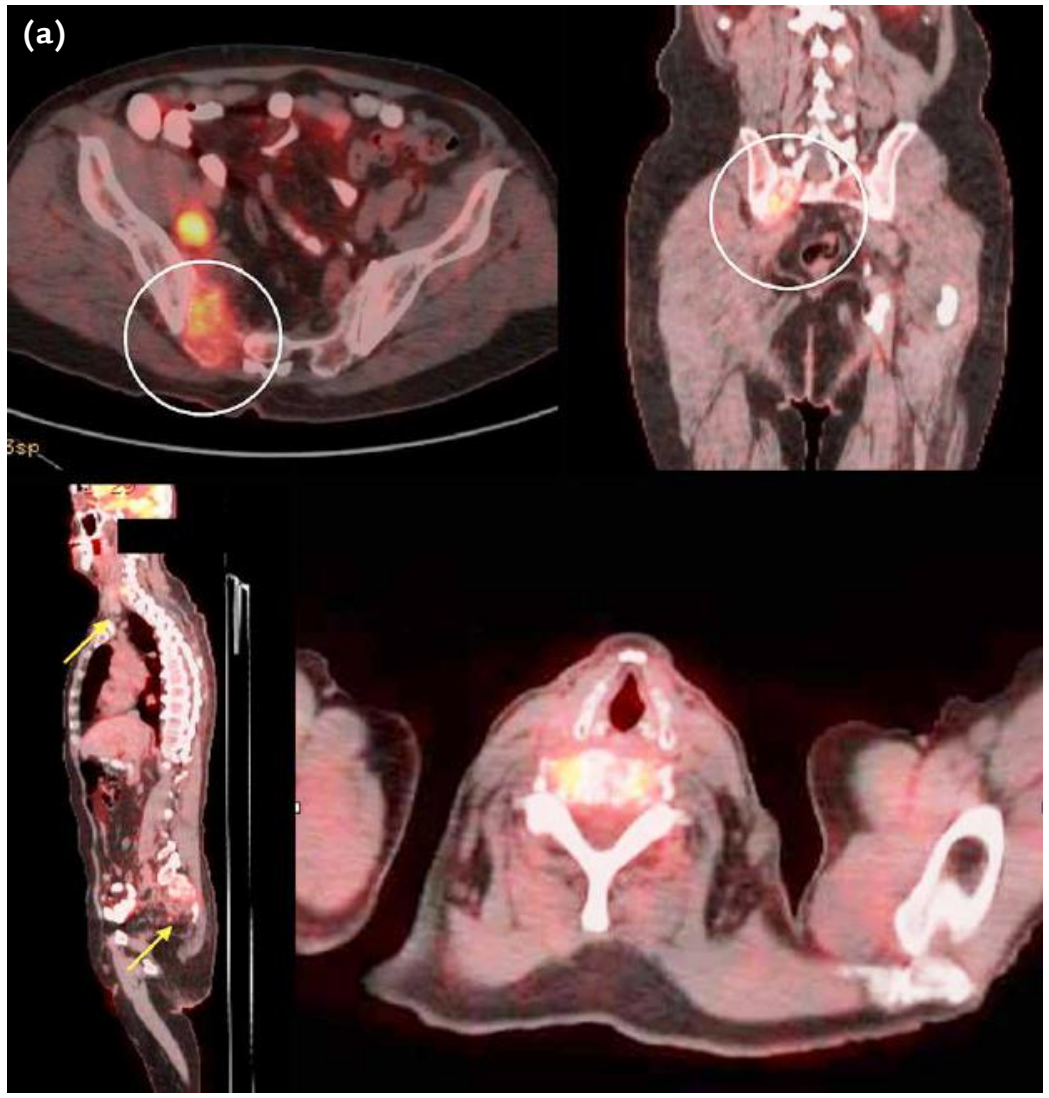

Şekil 2. a-c. Metastatik prostat karsinomu hastasında servikal omurga lezyonu lokal radyoterapiye cevap vermiş, ancak sakral lezyonda progresyon izlenmiştir. Hastada RFA ve sakroplasti sonrası tam radyolojik lokal kontrol ve klinik yanıt elde edilmiştir. Uygulama öncesi manyetik rezonans (MR) görüntülerinde, lezyonda çok belirgin kontrastlanma varken, uygulama sonrası görüntülerde kontrast tutulumun olmadığı görülmektedir.
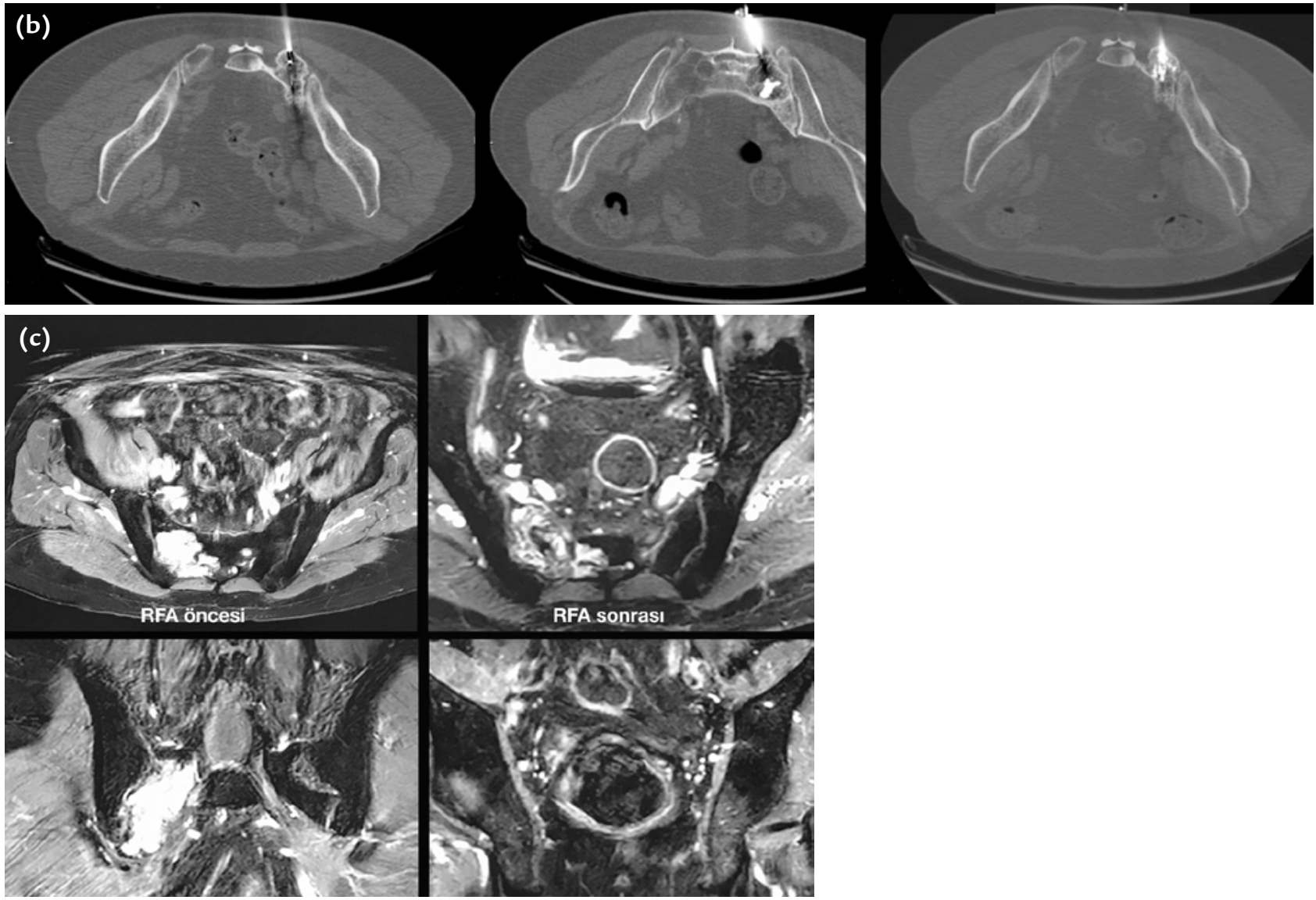

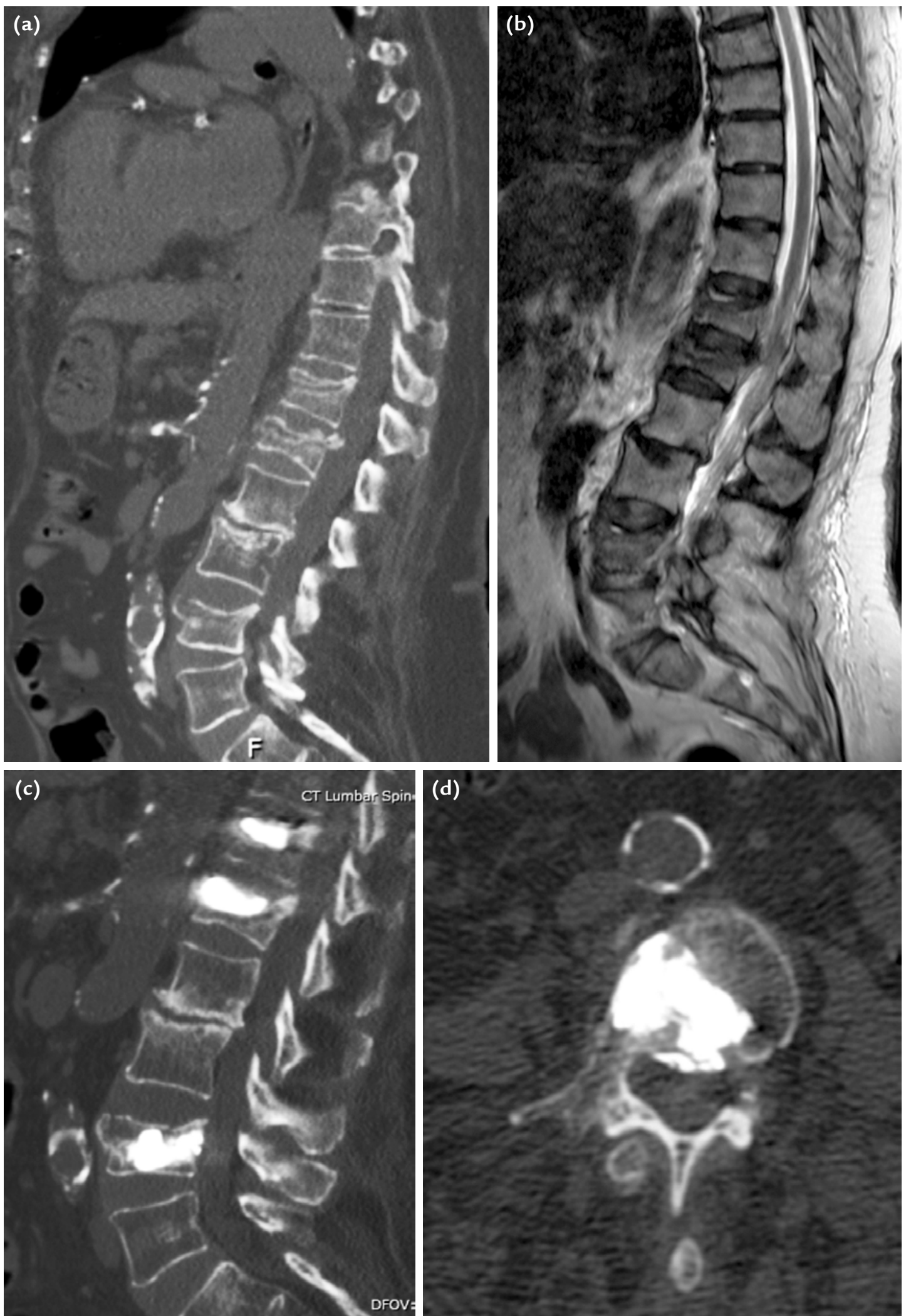

(d)

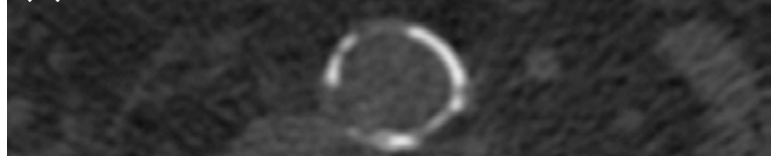

Şekil 3. a-d. Omurgada perkütan kemik çimentosu enjeksiyonları sonrası çimento kaçağı, nadir olmayan, ancak çoğunlukla asemptomatik seyreden bir komplikasyondur. Çoklu omurga kırığıyla başvuran bir multipl miyelom hastasında, üç seviye PVP sonrası L5 omurgada epidural çimento kaçağı, hastada herhangi bir klinik bulguya yol açmamıştır. 
Her iki yöntemle ilgili önemli bir kaygı da çimento enjeksiyonu sırasında, omurga içindeki basıncın artmasına bağlı dolaşıma tümör hücrelerinin salınımıdır. Prognostik açıdan önemli bir risk teşkil eden bu konuya ilişkin Mohme ve ark. tarafından yapılan çalışmada, PVP/PKP sonrası dolaşıma katılan tümör hücrelerinin sayısında önemli bir artış olduğu gösterilmiştir. Bu veri, söz konusu girişim öncesi canlı tümör hücresi yayılımını azaltmaya yönelik stratejilerin (ameliyat öncesi RT, RFA, ameliyat esnasında RT gibi) önemini ortaya koymaktadır. ${ }^{[14]}$

Perkütan sementoplasti, vertebrada popüler bir uygulama olmakla birlikte, pelvis (sıklıkla asetabulum) ve uzun kemiklerde de başarılı sonuçlar elde edilmektedir. ${ }^{[15]}$ Uzun kemiklerde tek başına çimento uygulanması kırık gelişimine engel olmayacağı için, yöntemin metalik implant ile kombine edilmesi gereklidir. $\mathrm{Bu}$ amaçla çok delikli vida ve çiviler geliştirilmiştir. Kemik çimentosunun içine kemoterapotik ve antiosteolitik ajanlar ve radyofarmasötikler eklenerek daha etkili ve uzun süren bir tümör kontrolü sağlanabileceğine yönelik olgu serileri bildirilmektedir. ${ }^{[16,17]}$

\section{RADYOFREKANS ABLASYON (RFA)}

RFA, alternatif akımın doku ısısı üretmesi, sonuçta protein denatürasyonu ve hücre ölümüyle sonuçlanan termal ablasyon yöntemidir. Benign lezyonlarda küratif, malign lezyonlarda özellikle metastazlarda ağrı azaltılması amacıyla uygulanmaktadır. Birçok çalışmada, konvansiyonel yöntemler başarısız kaldığında bu yöntemle yüksek oranda ağrı azalması sağlandığı gösterilmiştir. ${ }^{[18-20]}$

Omurga ve ekstremitede RFA ve kemik çimentosu enjeksiyonu kombine edildiğinde, özellikle litik metastazlarda, sinerjistik bir etkiyle daha da etkili bir ağrı azaltılması elde edilmektedir. RFA, tümörün yoğunluğunu ve hacmini azaltarak ve tümör hücreleri arasındaki bağlantıları tahrip ederek, kemik çimentosunun doku içinde daha homojen yayılımını sağlar; aynı zamanda, kemik iliğindeki canlı tümör hücrelerinde koagülasyon nekrozuna yol açarak, sementasyon sırasındaki basıncın yaratacağı lokal ve sistemik tümör yayılımı riskini azaltır. RFA sonrası çimentonun enjekte edilmesiyle hızIı bir trabeküler kemik stabilizasyonu sağlanırken, sement enjeksiyonunun RFA'ya ek olarak termal ve direkt kimyasal toksik etkisiyle, duyusal ağrıya duyarlı periosteal sinir uçları aktivitesinde belirgin azalma sağlanır.

RFA'nın PVP/PKP ile kombinasyonu, özellikle omurganın litik metastazlarında çökmenin engellenmesi için önerilmektedir. Son yıllarda, RFA ve PMMA enjeksiyonu uygulaması ardından lokal RT uygulanması ile, oldukça etkili ağrı azaltılması ve düşük lokal nüks sağlanabileceği bildirilmektedir. ${ }^{[21,22]}$
Perkütan RFA, BT veya ameliyat esnasında BT ve floroskopi kombinasyonu ile uygulanabilir. Özellikle RFA sonrası kemik çimentosu enjeksiyonu planlanıyorsa, işlemin daha hızı ıygulanması açısından floroskopi gereklidir (Şekil 4). Özellikle omurga uygulamalarında, blastik lezyonlar veya RT sonrası skleroz gelişen olgularda, cerrahi çekiç, kanüllü matkap uçları ve elektrikli motor hazır bulundurulmalıdır. Biz kendi olgularımızda, özellikle omurgada etkili bir ablasyon zonu sağlamak amacıyla, bi-pediküler yaklaşımla "probe kissing" pozisyonu elde etmek için, BT ile işleme başlamayı, ardından PVP/PKP uygulamasını floroskopi altında yapmayı tercih ediyoruz (Şekil 5).

İdeal olarak, tümörlü bölgenin 0,5-1 cm ötesine geçecek şekilde koagülasyon nekrozu sağlanmalıdır. Uygun prob seçimi, tümörün ve tutulan kemiğin anatomik lokalizasyonuna göre belirlenmelidir. Bu amaçla, Medtronic Osteocoo/ ${ }^{\mathrm{TM}}$ tip RF sistemi, gerek dört ayrı prob seçeceği gerekse oldukça güvenli bir ablasyon uygulaması sunması nedeniyle, tarafımızdan tercih edilmektedir. Bu sistemde, ablasyon sonrası aynı set kullanılarak PMMA uygulaması da yapılabilmektedir. Buna ek olarak, radyofrekans enerjisi ve buna bağlı olarak ısının yavaşça artmasıyla dokuda kömürleşme meydana gelmeden daha geniş bir zonda etkili bir nekroz sağlanması, sistemin temel avantajlarını oluşturmaktadır. Bilindiği gibi, doku sıcaklığının $50{ }^{\circ} \mathrm{C}$ ve üzerine çıkması ile protein denatürasyonu başlar, 60-90 ${ }^{\circ} \mathrm{C}$ sıcaklıkta koagülasyon nekrozu oluşur, $100{ }^{\circ} \mathrm{C}$ 'nin üzerinde ise kömürleşme ve dokunun buharlaşması söz konusudur. Yüksek doku sıcaklığına kısa sürede çıkılması durumunda, ablasyon zonu probun yakın çevresi ile sınırlı kalacak ve radyofrekans enerjisi hedef bölgeye etkili olamayacaktır. Sıcaklık artışının kontrollü ve yavaşça sağlanması etkili bir ablasyon zonu sağlanabilmesi için önemlidir.

Özellikle omurga ve majör nörolojik yapılara komşu ekstremite lokalizasyonlarında, istenmeyen termal hasarı önlemek için koruyucu önlemler alınmalıdır. Bunun için, ablasyon zonu ile nöral yapıların birbirinden uzaklaştırılması amacıyla sıvı enjeksiyonu (hidrodisseksiyon) uygulanabilir. ${ }^{[23]}$ Ayrıca, uygulama setinde rutin bulunan Isı duyargaçları (thermocouples) ile, hedef sıcaklığın üzerine çıkıldığında sistemin otomatik olarak kapanması sağlanmaktadır (Şekil 6). Ablasyon işleminin tamamlanmasının ardından PMMA enjeksiyonu uygulanacak ise, doku ısısının düşmesi ve aşırı ısınmayı önlemek amacıyla yaklaşık 15 dakika beklenmesi gerekir. Gereken olgularda çimento enjeksiyonu sonrası işlem sonlandırılır.

RFA işlemi ağrılı bir uygulama olduğu için, biz bunu genel veya bölgesel anestezi altında uygulamayı tercih ediyoruz. Ancak, genel durumu bozuk hastalarda, 

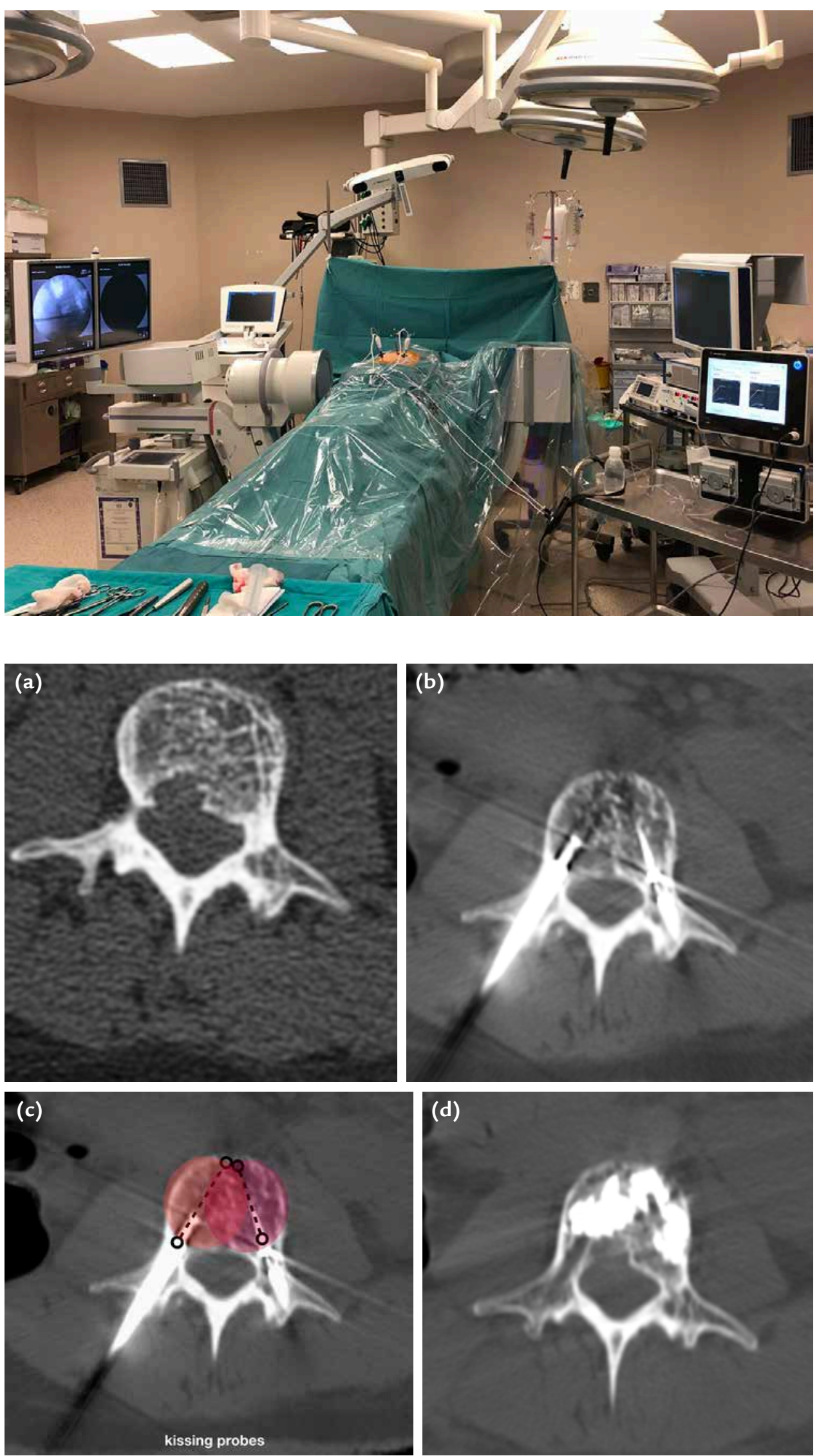

Şekil 4. Ameliyat esnasında BT ve floroskopi kombinasyonu. Özellikle omurgada, perkütan ablasyon ve çimento uygulamasında etkilidir. Güvenli bir uygulama sağlamaktadır.
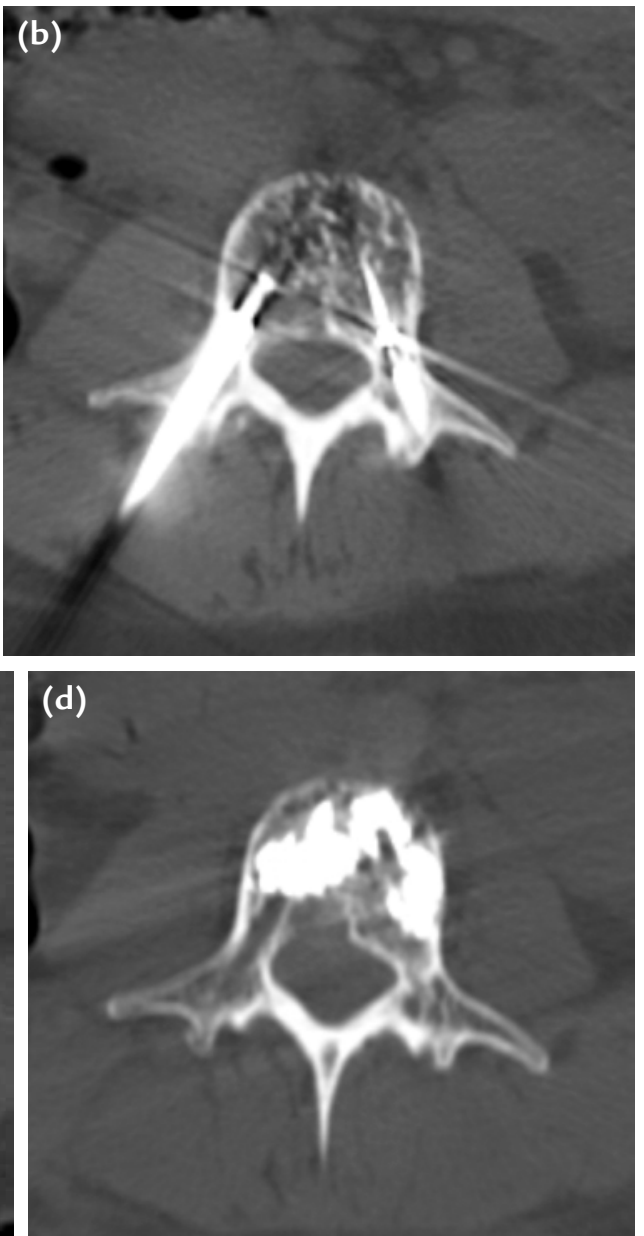

Şekil 5. a-d. Omurgada, posterior duvarın sağ tarafta destrükte olduğu lezyonda "probe kissing” tekniği ile elde edilen ablasyon zonu ve ardından çimento uygulaması. 

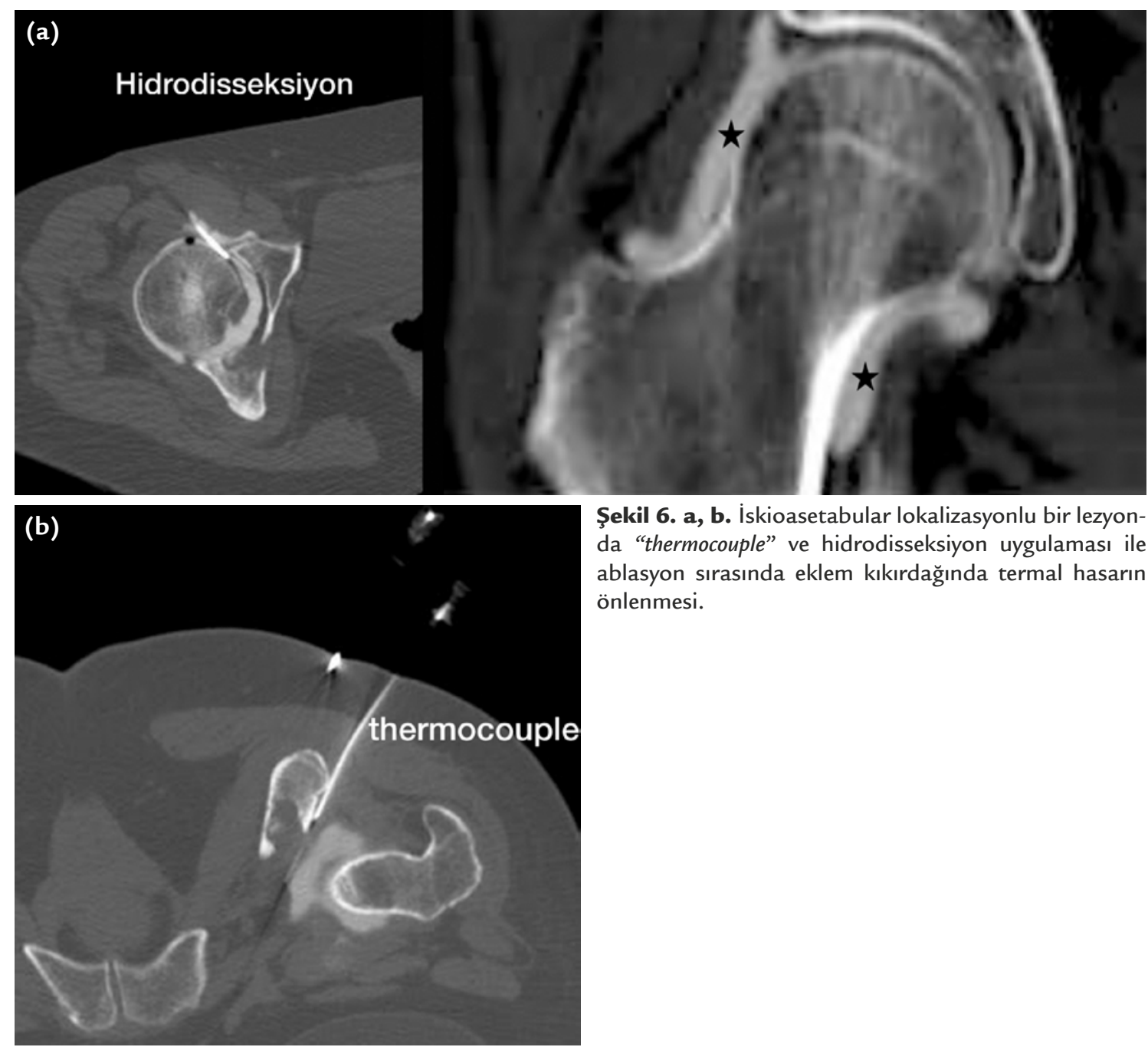

Şekil 6. a, b. İskioasetabular lokalizasyonlu bir lezyonda "thermocouple" ve hidrodisseksiyon uygulaması ile ablasyon sırasında eklem kıkırdağında termal hasarın önlenmesi.

lokal anestezi ve bilinçli sedasyon altında uygulama da yapılmaktadır. Birçok hastada sistemik sorunlar bulunduğu göz önüne alındığında, profilaktik antibiyotik ve hattâ çimentoya antibiyotik eklenmesi, enfeksiyonun önlenmesi açısından yararlı olabilir.

RFA, lokal enfeksiyon, kontrolsüz koagülopati ve pacemaker varlığında uygulanmamalıdır. Nöral yapılara çok yakın tümörler veya omurgada tümörün epidural bölgeye yayılmış olması, nörolojik defisit açısından risk oluşturacağı için, termo-protektif önlemler alınmalı, riskli olgularda gerektiğinde açık cerrahi yapılabilecek alt yapı hazır olmalıdır. Son olarak; tümüyle blastik metastazlarda RF ablasyon yerine KA uygulanması önerilmektedir.

İskelet metastazlarında RFA yöntemi, komplikasyon oranları açısından güvenli bir yöntemdir. Komplikasyonlar genellikle girişim sonrası erken dönemde görülür. Cilt ve cilt altı yumuşak doku hasarı minör bir komplikasyon olarak bildirilmekle birlikte, kendi olgularımızda hiç karşılaşmadığımızı belirtmek isteriz. Bu konuda alınacak basit önlemler; özellikle, soğutma sistemli prob kullanımı, diğer sistemlerde ablasyon bitiminde soğuma için yeterli süre beklenmesi, el ve ayak gibi cilde çok yakın lokalizasyonlarda uygulamadan kaçınmak, olarak özetlenebilir.

Hemoraji, solid organ uygulamaları ile kıyaslandığında son derece nadir görülen bir komplikasyondur. Yine de, vasküler tümörlerde hemoraji olabileceği göz önünde tutulmalıdır. Son olarak, nörolojik yaralanma ve buna bağlı sorunlar, özellikle majör nörolojik yapılara yakın veya omurga yerleşimli tümörlerde görülebilir. Yukarıda belirtilen termo-protektif önlemler ve probların BT altında yerleştirilmesi sayesinde, majör nörolojik hasardan kaçınmak mümkün olmaktadır (Şekil 7).[24] 

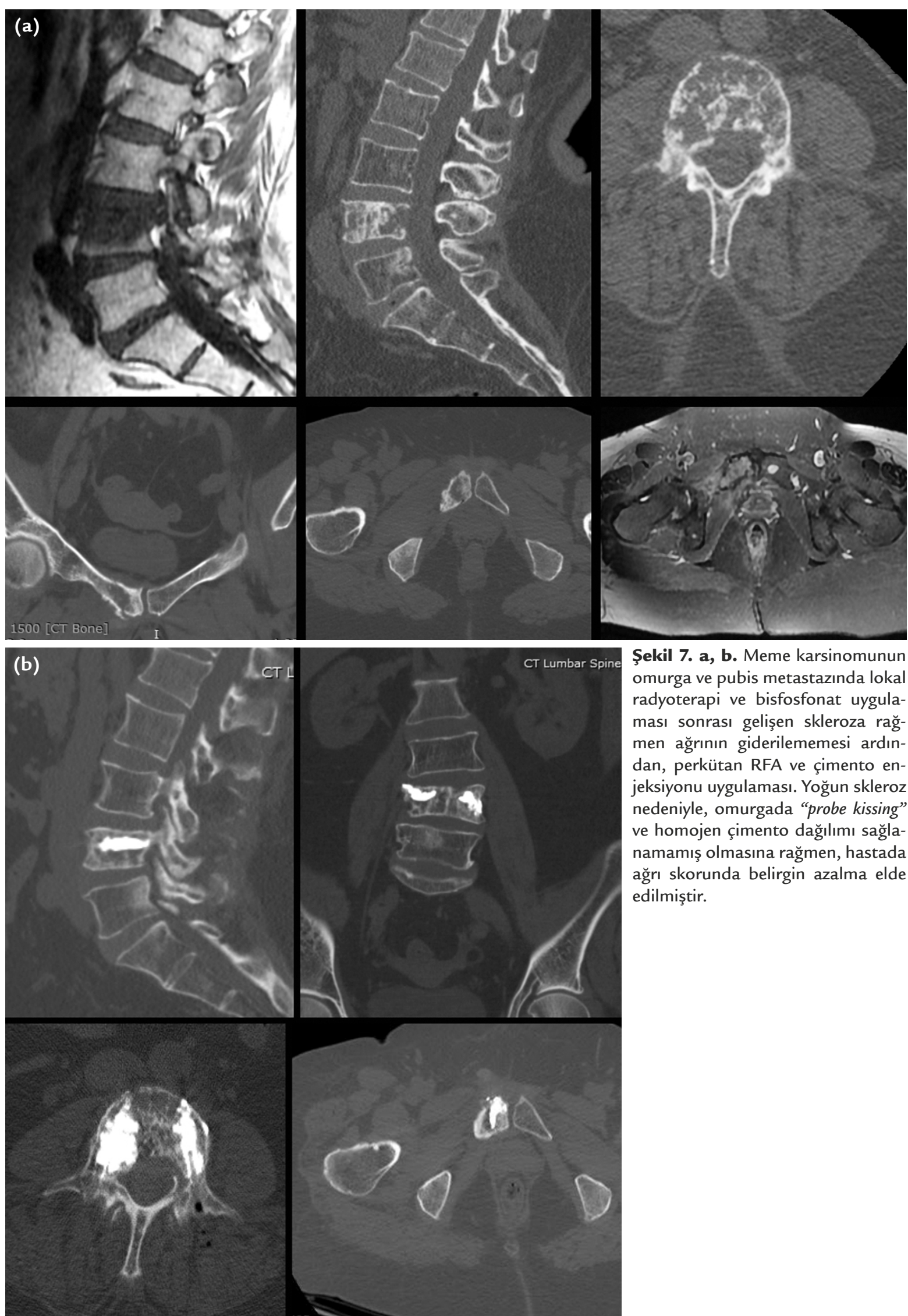

Şekil 7. a, b. Meme karsinomunun omurga ve pubis metastazında lokal radyoterapi ve bisfosfonat uygulaması sonrası gelişen skleroza rağmen ağrının giderilememesi ardından, perkütan RFA ve çimento enjeksiyonu uygulaması. Yoğun skleroz nedeniyle, omurgada "probe kissing" ve homojen çimento dağılımı sağlanamamış olmasına rağmen, hastada ağrı skorunda belirgin azalma elde edilmiştir. 


\section{KRIYOABLASYON (KA)}

Görüntüleme eşliğinde perkütan KA, metastatik kemik lezyonlarının palyatif tedavisinde uygulanan diğer bir yöntemdir. RFA uygulamalarında olduğu gibi, patolojik kırık açısından riskli olgularda yönteme ek olarak kemik çimentosu enjeksiyonu eklenmelidir. Diğer termal ablasyon yöntemleri ile kıyaslandığında, çok sayıda prob yerleştirerek daha geniş alanda ablasyon elde edilebilmesi ve ablasyon zonunun BT'de görüntülenebilmesi gibi avantajları ile öne çıkmaktadır. Daha önce belirtildiği gibi, özellikle blastik lezyonlarda RFA yöntemine kıyasla daha etkilidir. ${ }^{[25]}$

Wallace ve ark., 56 hastada 92 KA uygulamışlar ve uygulama sonrası 3. aya kadar bir sürede, ağrıda belirgin azalma elde ettiklerini bildirmişlerdir. Yazarlar, KA sonrası 6. aydaki ağrı skorlarının KA öncesi değerlere yakın olduğunu rapor etmekle birlikte, bu dönemde ancak yedi hastadan $11 \mathrm{KA}$ uygulama verilerinin değerlendirilebildiği vurgulanmaktadır. Benzer şekilde, radyolojik lokal kontrol oranlarının 3., 6. ve 12. aylarda sırasıyla \%90, 86 ve 79 olduğu görülmektedir. ${ }^{[25]}$

Benzer şekilde, Carlstrom ve ark. ${ }^{[26]}$ ile Prologo ve ark. $^{[27]}$ tarafından yapılan çalışmalarda, KA yönteminin, çeşitli primer karsinom metastazlarında ağrı azaltılması üzerine etkinliği gösterilmiştir.

Yukarıda bahsedilen üç çalışma gözden geçirildiğinde, KA yönteminin genel olarak güvenli olduğu, komplikasyon oranlarının yaklaşık \%4-11 arasında değiştiği görülmektedir. Görülen majör komplikasyonlar arasında; osteomiyelit, patolojik kırık, nörolojik sorunlar ve hemotoraks sayılabilir. Carlstrom ve ark., toraks duvarı metastazları olguları incelendiğinde hemotoraksın 2/13 olguda (\%15) olduğunu ve hastaların bu komplikasyon hakkında bilgilendirilmesi gerektiğini belirtmektedirler. ${ }^{[26]}$ Bununla birlikte, açık cerrahi alternatifi ile kıyaslandığında, söz konusu hasta grubunda komplikasyon oranlarının oldukça düşük ve kabul edilebilir sınırlarda olduğu görülmektedir.

\section{SONUÇ}

Ağrılı ekstremite ve omurga metastazlarının tedavisinde, PVP/PKP, RF ve KA, etkili ve hızlı bir ağrı azaltılması sağlayan, komplikasyon oranları düşük yöntemler olarak öne çıkmaktadır. Bu yöntemlerin ameliyat öncesi, ameliyat esnasında veya ameliyat sonrası RT ile kombinasyonuyla, daha uzun süreli etki ve lokal tümör kontrolü elde edilebilmektedir.

$\mathrm{Bu}$ tedavi seçenekleri, özellikle açık cerrahiyi tolere edemeyecek hastalarda, standart tedavi yöntemleri ile etkili bir ağrı azaltılması sağlanamayan durumlar ile KT ve RT gibi primer tedaviye erken başlanmasının ciddi önem kazandığı olgularda palyatif bir tedavi alternatifi olarak değerlendirilmelidir.

\section{KAYNAKLAR}

1. Nielsen OS, Munro AJ, Tannock IF. Bone metastases: Pathophysiology and management policy. J Clin Oncol 1991;9(3):509-24. Crossref

2. Kang HG, Kang SH. Minimal Invasive Surgery of Metastatic Bone Tumor, Chapter 7. https://doi.org/10.5772/64341 In: Xu K, editor. Tumor Metastasis. IntechOpen; 2016. pp.12741. Crossref

3. Manglani $\mathrm{HH}$, Marco RA, Picciolo A, Healey JH. Orthopedic emergencies in cancer patients. Semin Oncol 2000;27(3):299-310.

4. Jacofsky DJ, Papagelopoulos PJ, Sim FH. Advances and challenges in the surgical treatment of metastatic bone disease. Clin Orthop Relat Res 2003;415(Supp):S14-8. Crossref

5. Galibert $\mathrm{P}$, Deramond $\mathrm{H}$, Rosat $\mathrm{P}$, Le Gars D. Preliminary note on the treatment of vertebral angioma by percutaneous acrylic vertebroplasty. Neurochirurgie 1987;33(2):166-8.

6. Ofluoglu O. Minimally invasive management of spinal metastases. Orthop Clin North Am 2009;40(1):155-68. Crossref

7. Shimony JS, Gilula LA, Zeller AJ, Brown DB. Percutaneous vertebroplasty for malignant compression fractures with epidural involvement. Radiology 2004;232(3):846-53. Crossref

8. Moussazadeh N, Laufer I, Werner T, Krol G, Boland P, Bilsky $\mathrm{MH}$, Lis E. Sacroplasty for cancer-associated insufficiency fractures. Neurosurgery 2015;76(4):446-50. Crossref

9. Dudeney S, Lieberman IH, Reinhardt MK, Hussein M. Kyphoplasty in the treatment of osteolytic vertebral compression fractures as a result of multiple myeloma. J Clin Oncol 2002;20(9):2382-7. Crossref

10. Alvarez L, Pérez-Higueras A, Quiñones D, Calvo E, Rossi RE. Vertebroplasty in the treatment of vertebral tumors: postprocedural outcome and quality of life. Eur Spine J 2003;12(4):356-60. Crossref

11. Calmels V, Vallée JN, Rose M, Chiras J. Osteoblastic and mixed spinal metastases: evaluation of the analgesic efficacy of percutaneous vertebroplasty. AJNR Am J Neuroradiol 2007;28(3):570-4.

12. Cotten A, Dewatre F, Cortet B, Assaker R, Leblond D, Duquesnoy B, Chastanet P, Clarisse J. Percutaneous vertebroplasty for osteolytic metastases and myeloma: effects of the percentage of lesion filling and the leakage of methyl methacrylate at clinical follow-up. Radiology 1996;200(2):525-30. Crossref

13. Bae JW, Gwak HS, Kim S, Joo J, Shin SH, Yoo H, Lee SH. Percutaneous vertebroplasty for patients with metastatic compression fractures of the thoracolumbar spine: clinical and radiological factors affecting functional outcomes. Spine J 2016;16(3):355-64. Crossref

14. Mohme M, Riethdorf S, Dreimann M, Werner S, Maire CL, Joosse SA, Bludau F, Mueller V, Neves RPL, Stoecklein $\mathrm{NH}$, Lamszus K, Westphal M, Pantel K, Wikman $\mathrm{H}$, Eicker SO. Circulating Tumour Cell Release after Cement Augmentation of Vertebral Metastases. Sci Rep 2017;7(1):7196. Crossref

15. Sun G, Jin P, Liu XX, Li M, Li L. Cementoplasty for managing painful bone metastases outside the spine. Eur Radiol 2014;24(3):731-7. Crossref

16. Özben H, Eralp L, Baysal G, Cort A, Şarkalkan N, Özben T. Cisplatin loaded PMMA. mechanical properties, surface analysis and effects on Saos- 2 cell culture. Acta Orthop Traumatol Turc 2013;47(3):184-92. Crossref 
17. Mazurkiewicz T, Matuszewski L, Matuszewska A, Jaszek M. Implanted bisphosphonates in bone cement affect bone markers in rat serum. Int Orthop 2013;37(5):969-74. Crossref

18. Callstrom MR, Charboneau JW, Goetz MP, Rubin J, Wong GY, Sloan JA, Novotny PJ, Lewis BD, Welch TJ, Farrell MA, Maus TP, Lee RA, Reading CC, Petersen IA, Pickett DD. Painful metastases involving bone: feasibility of percutaneous CT- and US-guided radio-frequency ablation. Radiology 2002;224(1):87-97. Crossref

19. Thanos L, Mylona S, Galani P, Tzavoulis D, Kalioras V, Tanteles $\mathrm{S}$, Pomoni M. Radiofrequency ablation of osseous metastases for the palliation of pain. Skeletal Radiol 2008;37(3):189-94. https://doi.org/10.1007/s00256-007-0404-5

20. Munk PL, Rashid F, Heran MK, Papirny M, Liu DM, Malfair D, Clarkson PW. Combined cementoplasty and radiofrequency ablation in the treatment of painful neoplastic lesions of bone. J Vasc Interv Radiol 2009;20(7):903-11. Crossref

21. Greenwood TJ, Wallace A, Friedman MV, Hillen TJ, Robinson CG, Jennings JW. Combined ablation and radiation therapy of spinal metastases: a novel multimodality treatment approach. Pain Physician 2015;18(6):573-81.

22. Di Staso M, Zugaro L, Gravina GL, Bonfili P, Marampon F, Di Nicola L, Conchiglia A, Ventura L, Franzese P, Gallucci M, Masciocchi C, Tombolini V. A feasibility study of percutaneous radiofrequency ablation followed by radiotherapy in the management of painful osteolytic bone metastases. Eur Radiol 2011;21(9):2004-10. Crossref
23. Garnon J, Cazzato RL, Caudrelier J, Nouri-Neuville M, Rao P, Boatta E, Ramamurthy N, Koch G, Gangi A. Adjunctive Thermoprotection During Percutaneous Thermal Ablation Procedures: Review of Current Techniques. Cardiovasc Intervent Radiol 2019;42(3):344-57. Crossref

24. Kurup AN, Callstrom MR. Ablation of musculoskeletal metastases: pain palliation, fracture risk reduction, and oligometastatic disease. Tech Vasc Interv Radiol 2013;16(4):253-61. Crossref

25. Wallace AN, McWilliams SR, Connolly SE, Symanski JS, Vaswani D, Tomasian A, Vyhmeister R, Lee AM, Madaelil TP, Hillen TJ, Jennings JW. Percutaneous imageguided cryoablation of musculoskeletal metastases: pain palliation and local tumor control. J Vasc Interv Radiol 2016;27(12):1788-96. Crossref

26. Callstrom MR, Dupuy DE, Solomon SB, Beres RA, Littrup PJ, Davis KW, Paz-Fumagalli R, Hoffman C, Atwell TD, Charboneau JW, Schmit GD, Goetz MP, Rubin J, Brown KJ, Novotny PJ, Sloan JA. Percutaneous image-guided cryoablation of painful metastases involving bone: multicenter trial. Cancer 2013;119(5):1033-41. Crossref

27. Prologo JD, Passalacqua M, Patel I, Bohnert N, Corn DJ. Image-guided cryoablation for the treatment of painful musculoskeletal metastatic disease: a single-center experience. Skeletal Radiol 2014;43(11):1551-9. Crossref 